\title{
PENGOLAHAN BUDI DAYA RUMPUT LAUT MENJADI AGAR-AGAR KERTAS UNTUK MITRA TANI DESA LONTAR
}

\author{
P.J.Suranto ${ }^{1}$, W.Sulistyawati ${ }^{2}$, S.Ginting ${ }^{3}$ \\ ${ }^{1}$ Jurusan Teknik Perkapalan, Universitas Pembangunan Nasional Veteran Jakarta \\ Surel: purwo.joko@unpnvj.ac.id \\ 2 Jurusan Teknik Perkapalan, Universitas Pembangunan Nasional Veteran Jakarta \\ Surel: w12n.sulistyawati.sby@gmail.com \\ ${ }^{3}$ Jurusan Teknik Perkapalan, Universitas Pembangunan Nasional Veteran Jakarta \\ Surel: sargiginting@upnvj.ac.id
}

\begin{abstract}
Seaweed cultivation from an economic perspective can provide a decent life for farmers. However, there needs to be alternative processing and packaging of products that have a higher selling value. A good product and selling price requires the right processing technology to become a business product in the community. One product that is quite promising in marketing and selling value is processing seaweed into paper jelly. This community service activity is carried out for the Productive Migrant Cooperative members, seaweed farmers, Lontar village, Tirtayasa subdistrict, Serang district, Banten province. The activity carried out is processing seaweed into paper jelly. The manufacture of seaweed into paper jelly went through experiments method to obtain a gelatin product with good elasticity and durability. This product does not require sophisticated technology so that home industries can do it. The seaweed used is Eucheuma cottonii which is harvested at the age of 40-45 days. The process carried out is by drying, crushing into slurry, printing and pressing. The size of the mould can be adjusted according to the wishes of farmers or market demand. This community service activity yielded a gelatinous paper size of $20 x 20 \mathrm{~cm}$, a thickness of about $0.5 \mathrm{~mm}$ to $1 \mathrm{~mm}$, and weight of 8 -grams to 10 grams per sheet. The advantages of this product from processing the Eucheuma cottonii type of seaweed have good elasticity, are durable and easy to pack.
\end{abstract}

Keywords : Alternative products, Aquaculture, Eucheuma cottonii seaweed, gelatinous paper

\begin{abstract}
ABSTRAK
Budi daya rumput laut dari segi ekonomi dapat memberikan kehidupan yang layak bagi petani. Akan tetapi perlu ada alternatif pengolahan dan pengemasan produk yang mempunyai nilai jual yang lebih tinggi. Suatu produk yang menjanjikan dan harga jual membutuhkan teknologi pengolahan yang tepat sehingga menjadi suatu produk usaha di masyarakat. Salah satu produk yang cukup menjanjikan dalam pemasaran dan nilai jual adalah mengolah rumput laut menjadi agar-agar kertas. Kegiatan pengabdian kepada masyarakat ini dilakukan kepada anggota Koperasi Migrant Produktif petani rumput laut desa Lontar kecamatan Tirtayasa kabupaten Serang, provinsi Banten. Kegiatan yang dilakukan adalah pengolahan rumput laut menjadi agar-agar kertas. Pembuatan rumput laut menjadi agar-agar kertas melalui metode percobaan hingga didapatkan produk agar-agar dengan tingkat elastisitas yang baik dan tahan lama. Produk ini tidak memerlukan teknologi yang canggih sehingga dapat dilakukan oleh industri rumahan. Rumput laut yang digunakan adalah jenis Eucheuma cottonii yang dipanen pada umur 40-45 hari. Proses yang dilakukan adalah dengan proses pengeringan, penghancuran menjadi bubur, pencetakan dan pengepresan. Ukuran cetakan bisa disesuaikan dengan keinginan petani atau permintaan pasar. Hasil dari kegiatan ini berupa agar-agar kertas ini dengan ukuran 20x20 cm ketebalan sekitar $0.5 \mathrm{~mm}$ sampai $1 \mathrm{~mm}$, berat perlembarnya antara 8 -gram sampai 10 gram. Kelebihan produk dari dari pengolahan rumput laut jenis Eucheuma cottonii ini mempunyai elastisitas yang baik, tahan lama dan mudah dikemas.
\end{abstract}

Kata kunci : Produk alternatif, Budidaya, Rumput laut Eucheuma cottonii, Agar-agar kertas

\section{PENDAHULUAN}

Rumput laut merupakan sumber mata pencaharian yang menjanjikan di wilayah pesisir pantai terutama di desa Lontar kecamatan Tirtayasa kabupaten Serang provinsi Banten. Rumput laut di Indonesia hampir seluruhnya didukung oleh kegiatan budidaya, berdasarkan data Kementerian Kelautan dan Perikanan, bahwa sekitar 99,73\% produksi rumput laut Indonesia berasal dari hasil 
budidaya (Priono, B., 2016). Potensi sumber daya terbesar di desa Lontar selain nelayan adalah budi daya rumput laut terbukti dari data profil desa yang dikeluarkan oleh desa Lontar dimana sebagian besar penduduknya merupakan nelayan sebanyak 1327 orang dan petani rumput laut sebanyak 1021 sehingga potensi sumber daya rumput laut di daerah ini sangatlah besar (sumber: desa Lontar tahun 2020). Lahan-lahan pertanian rumput laut berada di sepanjang pesisir pantai sejauh kurang lebih $1 \mathrm{~km}$ dari bibir pantai dengan kedalaman $20 \mathrm{~cm}$ s/d $50 \mathrm{~cm}$ dengan jenis rumput laut yang ditanam adalah Eucheuma cottonii. Pertumbuhan dan produksi rumput laut Eucheuma cottonii tertinggi adalah yang ditanam pada kedalaman $30 \mathrm{~cm}$ (Serdiati, N. and Widiastuti, I.M., 2010).

Pada waktu musim panen rumput laut basah dan kering terjual melalui pedagang pengumpul dengan harga yang tidak stabil. Harga ini ditentukan oleh pengumpul, karena petani belum mempunyai bargaining power dalam penentuan harga jual, namun masyarakat petani tetap berupaya menanam rumput laut (Ngamel, A.K., 2012)

Hasil panen rumput laut yang melimpah di desa Lontar selama ini hanya dijemur untuk dikeringkan dan langsung dijual ke pasaran sehingga harganya tidak begitu menjanjikan, maka untuk itu perlu dicari terobosan untuk mengolah hasil budidaya rumput laut tersebut agar hasil penjualan lebih bisa menjanjikan daripada sebelum diolah, sehingga diharapkan dapat meningkatkan kesejahteraan warga masyarakat di desa Lontar.

\section{METODE PELAKSANAAN PKM}

Metode pembuatan agar-agar kertas ini menggunakan metode percobaan, setelah percobaan berhasil maka dilanjutkan dengan pelaksanaan PKM di desa Lontar, Tirtayasa, Serang, Banten, dengan terlebih dahulu mengadakan survey lokasi serta meminta ijin kepada kepala desa setempat di kantor kepala desa Lontar, supaya dapat dilaksanakannya PKM pembuatan agar-agar kertas di desa tersebut. Pelaksanaan PKM ditujukan kepada anggota Koperasi Migrant Produktif petani rumput laut di desa Lontar dengan metode pelaksanaannya berupa penyuluhan dan pelatihan mengenai pembuatan agar-agar kertas, untuk lebih jelasnya bisa dilihat pada diagram alir sebagaimana ditampilkan pada gambar 1 .
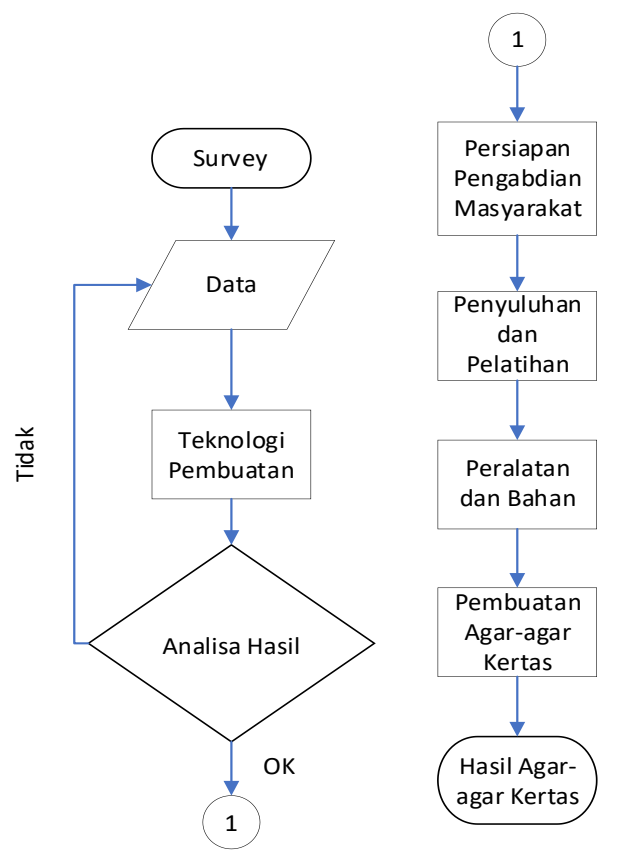

Gambar 1. Diagram Alir PKM 


\section{Survey}

Dengan adanya survey lokasi dimaksudkan agar pelaksanaan Pengabdian kepada Masyarakat dapat tepat sasaran. Ditentukan Lokasi survey untuk pelaksanaan PKM adalah di desa Lontar kecamatan Tirtayasa, Kabupaten Serang, Provinsi Banten.

\section{Data}

Desa Lontar terletak di pesisir pantai provinsi Banten dengan luas wilayah 556,5 Ha. Data mata pencarian atau pekerjaan masyarakat di desa Lontar kecamatan Tirtayasa, Kabupaten Serang, Provinsi Banten adalah sebagaimana data yang didapat dari Kantor Kepala Desa Lontar, dimana profil masyarakat di desa tersebut sebagian besar merupakan nelayan dan petani rumput laut sebagaimana ditampilkan pada tabel 1 .

Tabel 1. Profil pekerjaan masyarakat desa Lontar.

\begin{tabular}{lr}
\hline \multicolumn{1}{c}{ JENIS PEKERJAAN } & JUMLAH (Orang) \\
\hline Nelayan & 1.327 \\
\hline Buruh Nelayan & 852 \\
\hline Petani Rumput Laut & 1.021 \\
\hline Karyawan & 50 \\
\hline Wiraswasta/pedagang & 80 \\
\hline TNI / Polri & 7 \\
\hline Buruh Migran & 1.029 \\
\hline Tani & - \\
\hline
\end{tabular}

Sumber: profil desa Lontar 2020

Jumlah Penduduknya ada 4.366 orang dengan jumlah kepala keluarga ada 1.837 kepala keluarga, dengan jumlah keluarga yang ekonominya masih dibawah rata-rata sebanyak 1.534 kepala keluarga atau $83,5 \%$ dari jumlah penduduknya (Profil desa Lontar, 2020).

\section{Teknologi Pembuatan}

Teknologi atau alat yang digunakan dalam pembuatan agar-agar kertas ini cukup sederhana sehingga bisa dibuat oleh siapa saja. Mulai dari tungku untuk merebus (gambar 2) yang bisa dibuat sendiri atau bahkan bisa menggunakan kompor yang sudah biasa digunakan. Selain itu juga ada alat pengiris (gambar 3) yang juga bisa dibuat sendiri oleh siapa saja dengan meggunakan kayu reng dan benang senar laying-layang atau benang pancing. Alat yang tidak kalah pentingnya adalah alat untuk pengepressan (gambar 4), alat inipun bisa dibuat sendiri oleh siapa saja, dengan mengunakan kayu dan multiplek atau bahkan bisa menggunakan suatu kolam persegi yang kecil, dimana pengepresannya bisa menggunakan jerigen besar yang diisi air sebagai pemberat yang nantinya ditaruh di atas agar-agar yang akan dipress atau ditekan. Tujuan pengepressan ini adalah untuk mengurangi kadar air dari agar-agar yang nantinya akan dijemur di panas matahari.

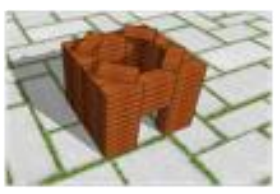

Gambar 2

Tungku dari Bata

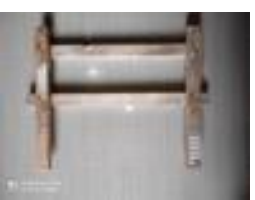

Gambar 3

Alat Pengiris

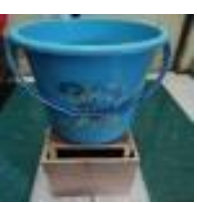

Gambar 4

Alat Pengepress 


\section{HASIL DAN PEMBAHASAN}

\section{Subyek PKM}

Peserta PKM ini adalah anggota Koperasi Migrant Produktif petani rumput laut di desa Lontar kecamatan Tirtayasa kabupaten Serang provinsi Banten dengan penyuluhan dan pelatihan di aula kantor kepala desa sebagaimana terlihat pada gambar 5.

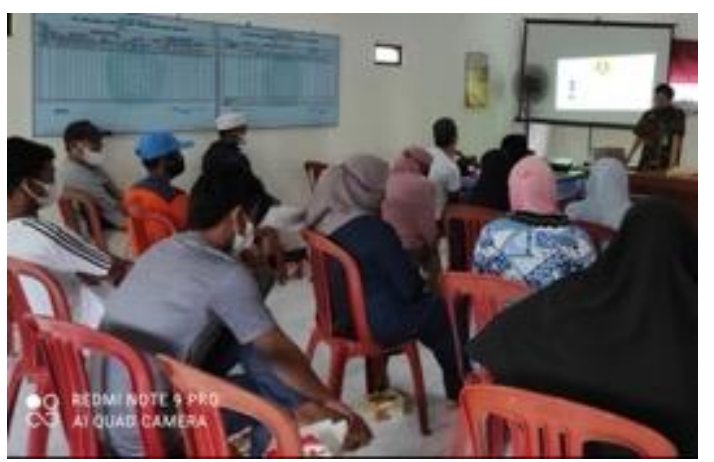

Gambar 5

Penyuluhan dan pelatihan Anggota Koperasi Migrant Produktif desa Lontar

\section{Bahan Yang digunakan}

Eucheuma cottonii merupakan salah satu komoditas prioritas, karena memiliki beberapa keunggulan yaitu teknologi budidaya mudah dilakukan, modal yang diperlukan dalam budidaya rumput laut relatif kecil, usia panen singkat (M Wijaya, K Kadirman, 2021). Usia panen rumput laut harus diperhatikan untuk mendapatkan rumput laut kering yang berkualitas. Pemanenan yang terlalu cepat atau lambat akan berakibat pada turunnya kualitas rumput laut (R Rofik, MF Oktafiyanto, S Syahiruddin. 2021). Rumput laut Eucheuma cottoni telah siap panen apabila telah memasuki umur panen 40-45 hari setelah penanaman. Sedangkan panen untuk kebutuhan bibit dilakukan pada saat memasuki umur 25-30 hari (DJPB, Kementerian Kelautan dan Perikanan, 2015). Rumput laut yang kualitasnya bagus adalah tergantung dari umur waktu panen, Adapun rumput laut yang bagus apabila dipanen umurnya sudah mencapai 40-45 hari baru bisa menghasilkan

Jenis Rumput Laut yang digunakan untuk dibuat agar-agar kertas ini adalah:

1. jenis Euchema cottonii (gambar 6).

2. Kapur sirih (gambar 7).

3. Air (gambar 8).

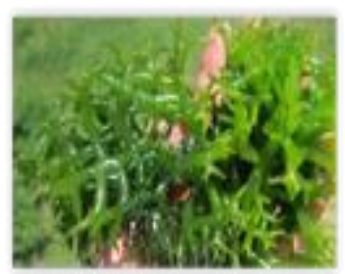

Gambar 6 Euchema cottonii

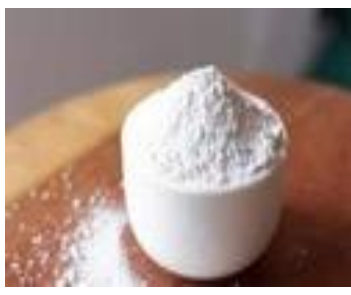

Gambar 7

Kapur Sirih

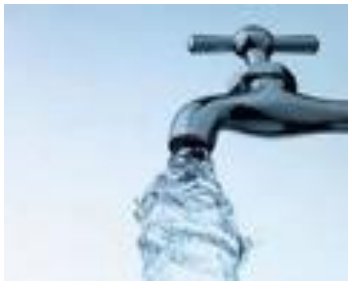

Gambar 8

Air Bersih

\section{Peralatan Yang digunakan}

Dalam pembuatan agar-agar kertas ini kita membutuhkan peralatan sebagai berikut: 


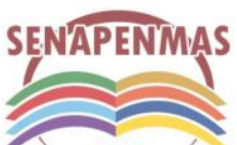

2021
Seminar Nasional Hasil Penelitian dan Pengabdian Kepada Masyarakat 2021

Pengembangan Ekonomi Bangsa Melalui Inovasi Digital Hasil Penelitian dan Pengabdian Kepada Masyarakat Jakarta, 21 Oktober 2021

1. Kompor (gambar 9) boleh juga tungku.

Gambar 9

Kompor

Kompor

2. Dandang atau panci (gambar 10).

Gambar 10

Panci

\begin{tabular}{lll} 
& Gamci \\
\hline $3 . \quad$ Pengaduk atau spatula (gambar 11) & Spatula \\
& & \\
& & \\
\hline
\end{tabular}

4. Loyang (gambar 12)

Gambar 12

Loyang

5. Alat pengiris (gambar 13)

Gambar 13

Alat Pengiris

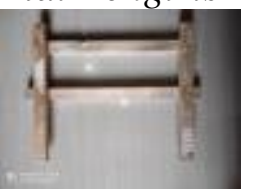

6. Kain blacu atau kain bekas karung terigu (gambar 14)

Gambar 14

Kain Blacu

7. Karung anyaman dari plastik atau karung Waring bisa bekas karung untuk bawang (gambar 15)

Gambar 15

Karung Waring

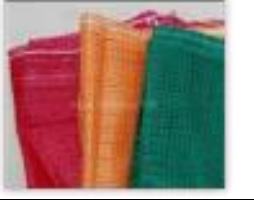

8. Saringan (gambar 16)

Gambar 16

Saringan

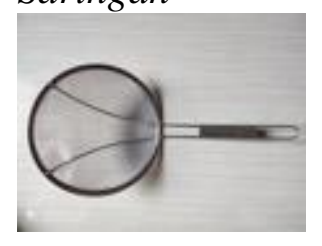




\begin{tabular}{lll}
\hline $10 \quad$ Ember (gambar 18) \\
Ember
\end{tabular}

$11 \quad$ Blender (gambar 19)

Gambar 19

Blender

12 Alat pengepress sederhana (gambar 20)

Gambar 20

Pengepress

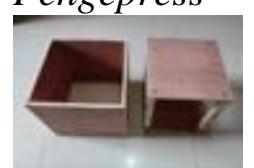

\section{Proses Pembuatan}

Pembuatan agar-agar bentuk kertas menggunakan rumput laut jenis Euchema cottonii yang dihasilkan oleh para petani rumput laut di desa Lontar, adapun proses pembuatannya sebagai berikut :

\footnotetext{
1. Rumput Laut ditimbang disesuaikan dengan Dandang atau pancinya perbandingan Rumput Laut dengan air adalah $1 \mathrm{~kg}$ rumput kering :18 Liter air (gambar 21)
}

\section{Rumput Laut dicuci dan dibersihkan (gambar 22)}

\section{Gambar 22}

\section{Dicuci}

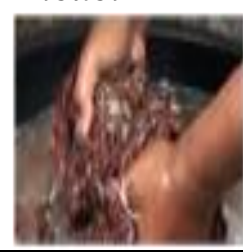

3. Perendaman ke dalam Larutan Kapur sirih 0,5\% selama 5 s/d 10 Gambar 23 menit (gambar 23) ini gunanya untuk:

Perendaman

- Pemucatan/pemutihan

- Menghilangkan bakteri

- Membantu proses menjadi agar-agar 
Seminar Nasional Hasil Penelitian dan Pengabdian Kepada Masyarakat 2021

Pengembangan Ekonomi Bangsa Melalui Inovasi Digital Hasil Penelitian dan Pengabdian Kepada Masyarakat Jakarta, 21 Oktober 2021

4. Dicuci lagi sampai berkali kali hingga bersih dan netral dari Gambar 24 kapur sirih sekaligus membersihkan kalo ada karang yg masih Pencucian menempel (gambar 24).

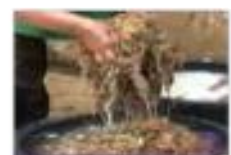

5. Dimasukan kedalam karung anyaman yang jarang-jarang dan diikat, supaya pada saat proses ekstaksi (perebusan) agar-agar msh terjaga di dalam karung (gambar 25)

Gambar 25

Dimasukan ke dalam

Karung Waring

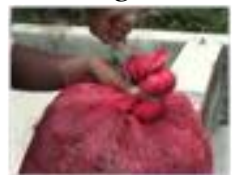

Gambar 26

Perebusan / Ekstraksi

- Dengan api besar.

- Perbandingan Rumput Laut Kering dan Air adalah $1: 14$

- Perebusan selama 2 jam

7. Dalam proses perebusan/ekstraksi rumput laut hancur dan keluar melalui pori-pori karung kemudian yang belum terekstraksi/hancur yang ada dikarung dikeluarkan terus digiling atau dihaluskan (gambar 27) ini bisa menggunakan mesin penggiling atau blender

8. Yang sudah dihaluskan dimasukkan kembali ke dalam rebusan, ini untuk mempercepat proses ekstraksi (gambar 28)

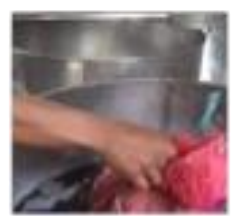

Gambar 27

Dihaluskan

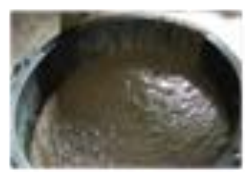

\section{Gambar 28}

Dituang ke dalam

rebusan kembali

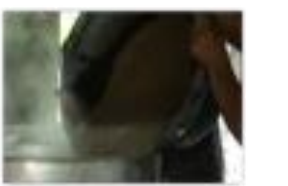

9. Kemudian disaring menggunakan kain tepung terigu atau kain Gambar 29 mori atau bisa juga menggunakan saringan (gambar 29)

Penyaringan

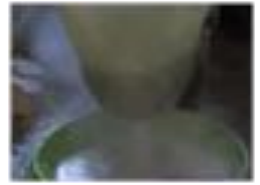

10. Hasil saringan dituang kedalam cetakan bentuk kotak (gambar Gambar 30 30)

Pencetakan

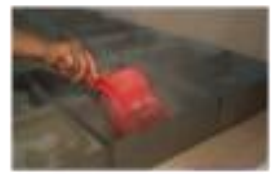

11. Setelah dingin dan membeku kemudian dikeluarkan dari cetakan (gambar 31)

Gambar 31

Dikeluarkan dari cetakan

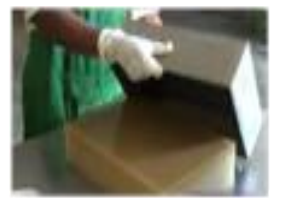




\begin{tabular}{|c|c|c|}
\hline 12 & $\begin{array}{l}\text { Kemudian diiris-iris setebal } 1 \mathrm{~cm} \text { dengan menggunakan alat } \\
\text { pengiris (gambar 32) }\end{array}$ & $\begin{array}{l}\text { Gambar } 32 \\
\text { Pepengirisan }\end{array}$ \\
\hline 13 & $\begin{array}{l}\text { yang sudah di iris-iris kemudian dibungkus dengan kain Mori } \\
\text { atau kain terigu supaya tdk mudah rusak atau patah (gambar 33) }\end{array}$ & $\begin{array}{l}\text { Gambar } 33 \\
\text { Dibungkus kain mori }\end{array}$ \\
\hline 14 & $\begin{array}{l}\text { Dipress atau ditekan semaleman dengan menggunakan alat } \\
\text { press yang bisa dibuat sendiri dengan diberi beban jerigen atau } \\
\text { ember dikasih air sebagai pemberat (gambar } 34)\end{array}$ & $\begin{array}{l}\text { Gambar } 34 \\
\text { Pengepress }\end{array}$ \\
\hline 15 & $\begin{array}{l}\text { Dijemur di terik matahari dibalik balik agar cepat kering } \\
\text { (gambar 35) }\end{array}$ & $\begin{array}{l}\text { Gambar } 35 \\
\text { Penjemuran }\end{array}$ \\
\hline 16 & $\begin{array}{l}\text { Kalo sudah kering agar-agar kertas dikelentek dari kain } \\
\text { pembungkusnya (gambar 36) }\end{array}$ & $\begin{array}{l}\text { Gambar } 36 \\
\text { Pengelentekan }\end{array}$ \\
\hline 17 & $\begin{array}{l}\text { Dipacking dan diberi merk siap di jual atau dipasarkan (gambar } \\
\text { 37) }\end{array}$ & $\begin{array}{l}\text { Gambar } 37 \\
\text { Packaging }\end{array}$ \\
\hline
\end{tabular}

Melalui program Blue Economy telah menerapkan rumput laut sebagai produk yang mempunyai potensi pasca panen yang dapat dikonsumsi masyarakat sebagai makanan sehat dan halal (BD Madusari, DE Wibowo, 2018)

Berdasarkan pengamatan langsung hasil berupa agar-agar kertas diperlihatkan pada gambar 38 mempunyai spesifikasi sebagai berikut:

1). Mempunyai ukuran sekitar $20 \mathrm{~cm} \times 20 \mathrm{~cm}$ tergantung dari ukuran loyang yang digunakan.

2). Mempumyai ketebalan yang tipis seperti kertas sekitar $0,5 \mathrm{~mm} \mathrm{~s} / \mathrm{d} 1 \mathrm{~mm}$.

3). Lumayan elastis sehingga bisa ditekuk-tekuk bila di packing atau dikemas.

4). Berat perlembar agar-agar kertas antara 8 gram s/d 10 gram.

Agar-agar kertas yang sudah jadi dapat dikemas atau dipacking sebagaimana di perlihatkan pada gambar 39, supaya bisa dijual / dipasarkan, sehingga dapat menambah peghasilan dan meningkatkan perekonomian masyarakat. 


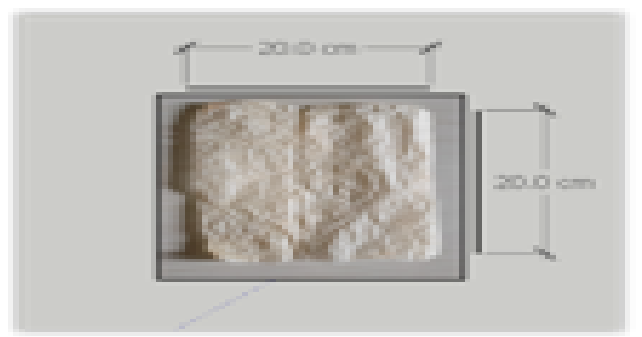

Gambar 38

Hasil berupa agar-agar kertas

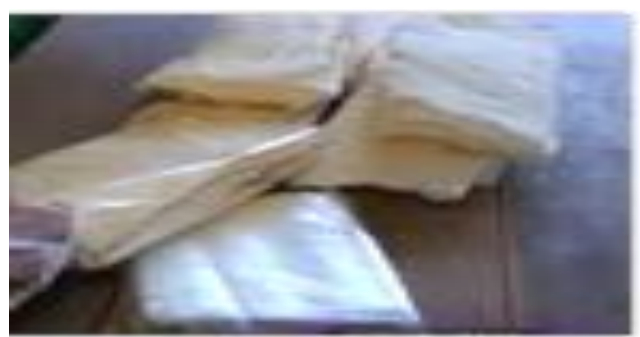

Gambar 39

Agar-agar kertas dikemas/dipacking

Cara memasaknya sangatlah mudah yaitu :

1. Tiga atau empat lembar agar-agar direndam dalam air dingin $2-3$ menit lalu buang airnya.

2. Dimasak dengan menggunakan 2 gelas air atau santan

3. Tambahkan gula merah/putih sesuai selera masing-masing boleh ditambah garam sedikit.

4. Rebus sampai mendidih Lalu tuangkan ke dalam cetakan atau loyang.

5. Didiamkan dan tunggu hinga dingin dan mengeras.

6. Siap dihidangkan/disajikan.

7. Bisa di olah menjadi beraneka macam hidangan puding gambar 40.
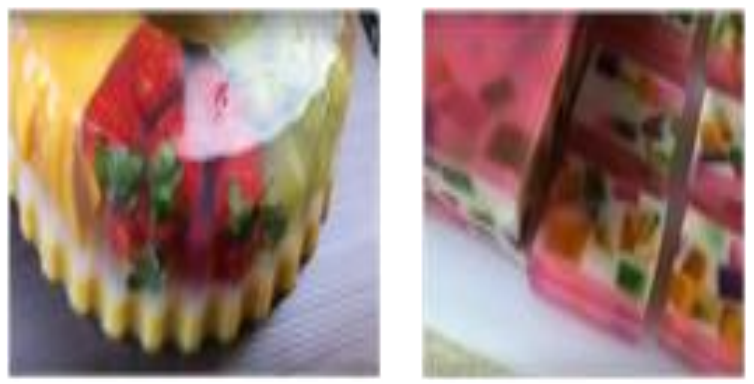

Gambar 40. Aneka Puding

\section{KESIMPULAN DAN SARAN}

Rumput laut hasil panen biasanya dijual dalam bentuk rumput laut kering atau belum di olah menjadi suatu produk yang dapat menghasilkan daya jual lebih tinggi dibandingkan bila di jual tanpa di olah. Adapun rumput laut yang digunakan untuk membuat agar-agar kertas adalah jenis rumput laut yang ditanam oleh masyarakat di desa Lontar yaitu jenis Euchema cottonii dan yang dipanen pada usia 40 hari sampai dengan 45 hari, rumput laut jenis ini cukup bagus digunakan untuk pembuatan agar-agar kertas. Teknologi atau alat yang digunakan dalam pembuatan agaragar kertas ini cukup sederhana bisa dibuat oleh siapa saja. Mulai dari tungku atau kompor untuk merebus, alat pengiris untuk mengiris, alat pengepress untuk mengurangi kadar air sebelum nantinya akan dijemur di panas matahari. Selain itu juga di bantu dengan peralatan lainnya yang umum digunakan sehari-hari. Proses atau urutan pembuatannya sangat mudah, sehingga bisa dilakukan oleh masyarakat khususnya oleh masyarakat petani rumput laut di desa Lontar.

Hasil berupa agar-agar kertas yang cukup baik yaitu tipis serta elastis dan mudah dikemas atau dipacking untuk dijual dan dipasarkan sebagai bahan pembuat makanan berbentuk jelly, sehingga akan dapat meningkatkan perekonomian masyarakat sekitar.

Pengolahan agar-agar bentuk kertas juga sangat mudah dan cepat, bisa diolah menjadi aneka macam puding atau jelly sesuai keinginan kita. 
Karena di desa tersebut jenis tanaman rumput lautnya adalah jenis Euchema cottonii sehingga perlu di coba dengan jenis rumput laut yang lainnya sehingga bisa mengetahui perbedaan hasil dari jenis rumput laut yang berbeda.

Ucapan Terima Kasih (Acknowledgement)

Terimakasih kepada semua pihak yang telah ikut membantu terlaksananya kegiatan Pengabdian Kepada Masyarakat ini, terutama kepada kepada Kepala Desa Lontar serta Ketua koperasi Desa Lontar yang telah mengijinkan pengabdian masyarakat ini dilaksanakan di desa tersebut.

\section{REFERENSI}

Madusari, B. D., \& Wibowo, D. E. (2018). Potensi dan peluang Produk Halal Berbasis Rumput Laut. Indonesia Journal of Halal, 1(1), 53-57.

Ngamel, A. K. (2012). Analisis finansial usaha budidaya rumput laut dan nilai tambah tepung karaginan di Kecamatan Kei Kecil, Kabupaten Maluku Tenggara.

Jurnal Sains Terapan, 2(1), 39-47.

Priono, B. (2016). Budidaya rumput laut dalam upaya peningkatan Industrialisasi perikanan. Media Akuakultur, 8(1), 1-8.

Rofik, R., Oktafiyanto, M. F., \& Syahiruddin, S. (2021). Pengaruh Umur Panen dan Metode Pengeringan terhadap Mutu Fisik Rumput Laut (Euchema spinosum). JURNAL AGROINDUSTRI HALAL, 7(1), 109-116.

Serdiati, N., \& Widiastuti, I. M. (2010). Pertumbuhan dan produksi rumput laut Eucheuma cottonii pada kedalaman penanaman yang berbeda. Media Litbang Sulteng, 3(1).

Wijaya, M., \& Kadirman, K. (2021). PENGARUH JARAK TANAM PADA BUDIDAYA RUMPUT LAUT (Eucheuma cottonii) TERHADAP SPESIFIKASI MUTU KARAGINAN.

Jurnal Pendidikan Teknologi Pertanian, 4, 242-249.

Direktorat Jenderal Perikanan Budidaya, (2015), Kementerian Kelautan dan Perikanan, diakses dari

https://www.djpb.kkp.go.id/index.php/mobile/arsip/c/261/CARA-PRAKTIS-MEMANENAN-RUMPUTLAUT-YANG-MEMENUHI-STANDAR-KUALITAS/?category_id=13

Profil desa Lontar, (2020), Sistem informasi desa Lontar, diakses dari http://desalontar132007.blogspot.com 